\title{
Assessing the causes for a relatively lower caseload of Covid-19 in South Asia Anum Niazi, ${ }^{1}$ Shandana Kifayat, ${ }^{2}$ Nasir Javed, ${ }^{3}$ Muhammad Salar Khan ${ }^{4}$
}

Abstract: In the wake of the ongoing spread of the Covid-19 pandemic, the number of affected persons has already surpassed 6 million globally. Advanced healthcare systems in North America and Western Europe have registered the highest number of cases. On the contrary, some of the weakest healthcare systems of the world, including those in South Asia, have observed significantly fewer cases of Covid-19. This article assesses the potential causes of a relatively lower caseload and lethality caused by Covid-19 in South Asia. Some of the key factors which might be creating favorable conditions for the relatively lower and less lethal spread of the virus in South Asia include an inconducive climate, reduced percentage of the elderly population, possible immunity due to existing disease trends, unfavorable blood group distribution, early lockdown restrictions, and lesser inbound and outbound movements as compared to Europe and North America. These observations are subject to discussion because most of the research is still preliminary, and the landscape of the disease is still shifting significantly on a daily basis. Lower incidence of Covid-19 in South Asia might well relate back to inadequate testing facilities and weak reporting protocols. The stigma associated with the illness and misinformation regarding treatment and healthcare administration might further lead to underreporting of the Covid-19 caseload. Various factors such as poverty, high population density, a large informal economy, and poor sanitation make South Asia particularly vulnerable. All these factors, combined with the recent easing of lockdown restrictions in the region, could lead to spikes in rates of Covid-19 infections. Therefore, we suggest the local governments collaborate and share technical and healthcare expertise to devise and implement comprehensive strategies to stop the spread of the disease. South Asia should swiftly mobilize local resources, quickly ramp up capabilities, and thoroughly implement the proposed guidelines. The public should practice prevention and precaution. The national governments (with the help of community elders and scholars) should

\footnotetext{
${ }^{1}$ MD Candidate, Windsor University School of Medicine, St. Kitts \& Nevis (Email: anum.niazi@student.windsor.edu)

${ }^{2}$ MD(MBBS), Trainee Medical Officer, Khyber Teaching Hospital, Peshawar

${ }^{3}$ Research Associate, Qureshi Law Associates, Islamabad Pakistan

${ }^{4}$ PhD Public Policy Candidate, Schar School of Policy and Government, George Mason University, Arlington Virginia (Email: mkhan63@gmu.edu)
} 
address stigma related to Covid-19. Finally, the international community must increase its technical assistance to mitigate the threats of the pandemic in populous South Asia.

\section{Article:}

In the wake of the ongoing spread of the Covid-19 pandemic, the number of affected persons has surpassed 6.3 million globally. ${ }^{1}$ The highest number of cases has been reported in the regions of North America and Western Europe, even though the healthcare systems of these regions have the highest per capita spending in the world. ${ }^{2} 3$ On the contrary, some of the weakest healthcare systems of the world, including those in Africa and South Asia, have observed significantly fewer cases of Covid-19 than Europe and North America. ${ }^{4}$ As of May 31, there are 331,346 confirmed cases (equivalent to 171 cases per million population) ${ }^{5}$ of Covid-19 in South Asia. In comparison, Europe and North America both have confirmed more than 2.03 million and 2.07 million cases, which is equivalent to 2,716 and $5,485^{6}$ cases per million of the population in these regions, respectively. ${ }^{7}$ Put differently, with a regional population of 1.9 billion, countries in South Asia (India, Pakistan, Bangladesh, Sri Lanka, Afghanistan, Nepal, Bhutan, and the Maldives) account for about one-quarter of the world's population but have only 5 percent of the global Covid-19 infections. ${ }^{8}$ One must wonder how South Asia is keeping the total number of cases low as compared to the regions of North America and Europe? This article will assess the potential causes of a relatively lower caseload of Covid-19 in South Asia.

Many ${ }^{9}$ attribute the low caseload of Covid-19 to weak healthcare infrastructure and inadequate testing facilities within the region. ${ }^{10}$ South Asian countries have thus far conducted a total of 5 million tests or 2592 tests for every 1 million people. ${ }^{11}$ These numbers attest to the lowest rates of testing in South Asia; but, if the region's low testing capacity were masking a mammoth breakout, it could have appeared in other ways. As of now, 6.6\% of Covid-19 tests in South Asia have been confirmed positive. On the other hand, the corresponding numbers in the major EU countries, such as in France, the UK, and the Netherlands are 13.64\%, 19.8\%, and 13.3\%, respectively, whereas it is $10.4 \%$ in the United States. ${ }^{12}$ The lower percentage of positive tests in South Asia indicates that Covid-19 is less prevalent in the region.

Alongside the number of confirmed cases, experts consider the number of deaths as a significant measure for the size of the outbreak. Here again, the data defies the notion of South Asia being in 
the worst shape with a death count of 7,893 from Covid-19, as of May 31, 2020. ${ }^{13}$ In comparison, the United States has reported more than 106,195 deaths, while the UK and Italy have recorded more than 38,489 and 33,415 deaths, respectively. ${ }^{14}$ The number of casualties caused by the Coronavirus in the regions of Europe and North America (the US and Canada) is significantly higher than in South Asia.

Table 1: Coronavirus Cases, Deaths, and Tests in South Asia vs. North America vs. Europe

\begin{tabular}{|l|l|l|l|l|l|l|l|l|l|}
\hline Date & $\begin{array}{l}\text { Cases } \\
\text { in } \\
\text { South } \\
\text { Asia }\end{array}$ & $\begin{array}{l}\text { Cases in } \\
\text { North } \\
\text { America } \\
\text { (US \& } \\
\text { Canada } \\
\text { only) }\end{array}$ & $\begin{array}{l}\text { Cases in } \\
\text { Europe }\end{array}$ & $\begin{array}{l}\text { Deaths } \\
\text { in South } \\
\text { Asia }\end{array}$ & $\begin{array}{l}\text { Deaths } \\
\text { in North } \\
\text { America } \\
\text { (US \& } \\
\text { Canada } \\
\text { only) }\end{array}$ & $\begin{array}{l}\text { Deaths } \\
\text { in } \\
\text { Europe }\end{array}$ & $\begin{array}{l}\text { Tests in } \\
\text { South } \\
\text { Asia }\end{array}$ & $\begin{array}{l}\text { Tests in } \\
\text { North } \\
\text { America } \\
\text { (US \& } \\
\text { Canada) }\end{array}$ & $\begin{array}{l}\text { Tests in } \\
\text { Europe }\end{array}$ \\
\hline $\begin{array}{l}\text { NUMBERS } \\
\text { AS OF } \\
\text { MAY 31, } \\
\text { 2020 }\end{array}$ & $\begin{array}{l}331,34 \\
6\end{array}$ & $\begin{array}{l}1,928,11 \\
7\end{array}$ & $\begin{array}{l}2,029,38 \\
9\end{array}$ & 7,893 & 113,490 & 173,904 & $\begin{array}{l}5,022,07 \\
6\end{array}$ & $\begin{array}{l}19,338,3 \\
98\end{array}$ & $37,609,28$ \\
\hline
\end{tabular}

(Source: Worldometer. May 31, 2020: https://www.worldometers.info/coronavirus/)

Potentially, the unreported number of deaths from Covid-19 could be higher in South Asia not only due to the stigma associated with the illness but also from the misinformation regarding treatment and healthcare administration. People might prefer to die in homes rather than in hospital wards. Secondly, not many deaths are medically registered in the region, thus leading to a low number of registered Covid-19 deaths (for instance, in India, over 75\% deaths are not medically certified under normal situations). ${ }^{15}$ Regardless of the reasons behind the low number of deaths, data on hospital admission does not witness a massive surge, which again put South Asia in a favorable spotlight. 
Table 2: Total Cases, Deaths, and Tests in all the Eight Countries Of South Asia (as of May 31, 2020)

\begin{tabular}{|c|c|c|c|c|}
\hline South Asian Countries & Cases & Casualties & $\begin{array}{l}\text { Number of } \\
\text { Tests }\end{array}$ & $\begin{array}{l}\text { Tests per } \\
\text { million }\end{array}$ \\
\hline India & 190,962 & 5,411 & $3,837,207$ & 2,783 \\
\hline Pakistan & 72,460 & 1,543 & 561,136 & 2,545 \\
\hline Bangladesh & 47,153 & 650 & 308,940 & 1,877 \\
\hline Sri Lanka & 1,633 & 11 & 65,355 & 3,053 \\
\hline Nepal & 1,572 & 8 & 180,691 & 6,211 \\
\hline Bhutan & 43 & 0 & 17,344 & 17,344 \\
\hline Maldives & 1,773 & 5 & 11,775 & 11,775 \\
\hline Afghanistan & 15,750 & 265 & 39,628 & 1,020 \\
\hline Total & 331346 & 7893 & $5,022,076$ & 2592.708312 \\
\hline $\begin{array}{l}\text { Positive Tests as total } \\
\text { percentage of the } \\
\text { population }\end{array}$ & 0.017097581 & & & \\
\hline Cases per million & 171.0614352 & & & \\
\hline $\begin{array}{l}\text { Positive Cases as a } \\
\text { percentage of Total Tests }\end{array}$ & 6.59778944 & & & \\
\hline
\end{tabular}

(Source: Worldometer. May 31, 2020: https://www.worldometers.info/coronavirus/)

Here we discuss some of the key factors which might be creating favorable conditions for the relatively lower and less lethal spread of the Coronavirus in South Asia.

The first notable factor could be the unfavorable climate of the South Asian region. Some initial research indicates that higher temperature and humidity correlates with a lower transmission of Covid-19. ${ }^{16}$ Countries with the highest number of Covid-19 patients are not as warm and dry as South Asia. The average temperature of South Asia is higher than that of Europe and North America. In other words, the South Asian regions are sunnier than Europe and Americas, which exposes the local population of South Asia more towards the sunlight and, consequently, towards obtaining a higher level of Vitamin-D naturally. As per a research article, a higher intake of Vitamin-D reduces the possibility of respiratory tract infections by fifty percent. ${ }^{17}$ Recent studies ${ }^{18}$ support the notion of Vitamin D preventing Covid-19. ${ }^{19}$ As basically, Covid-19 is also a respiratory tract virus; therefore, possibly, the people of South Asia may have developed a higher level of immunity from Covid-19 than what is possessed by the people residing in European and American 
regions. Probably, this may be keeping the overall number of Covid-19 cases and resulting deaths significantly lower in South Asia.

Another possible reason for the low rate and mortality from Covid-19 in South Asia could be that the majority of people in the Indian Subcontinent (Pakistan, India, and Bangladesh) have an ABO blood type of $\mathrm{B}(\mathrm{B}>\mathrm{O}>\mathrm{A}>\mathrm{AB})$ which is deemed favorable than A blood types. ${ }^{20}$

While studying a possible association between ABO blood types and Covid- $19^{21}$ in the Wuhan and Shenzhen cities of China, Zhou and colleagues report those with blood type-A have a higher risk of receiving infection as compared to those with blood type $\mathrm{O}$, which has a lower infection rate. $^{22}$ Specifically, the study shows that patients with an increased risk of Covid-19 and blood group A had an odds ratio (OR) of 1.279 (28\% more chance), whereas patients with decreased risk of Covid-19 and blood group O had an OR of 0.680 (32\% less chance). ${ }^{23}$ While examining this similar question, researchers at New York Presbyterian Hospital pooled their data with the research by Zhao and colleagues. They confirmed the results and also found a significant drop in positive Covid-19 cases among blood type B individuals. ${ }^{24}$

Higher susceptibility of blood group A and lower susceptibility of blood group O can be linked to the natural anti-blood group antibodies, more specifically, anti-A antibodies, which limit the adhesion of SARS-CoV S protein to ACE2 expressing cell lines. ${ }^{25}$ These anti-A antibodies which limit adhesion are found on both $\mathrm{O}$ and $\mathrm{B}$ blood types, which might suggest why populations with these blood groups are responding better to Covid-19. Previous data indicate that the Norwalk virus and Hepatitis B have a clear blood group susceptibility, making type A blood types more prone to the infection. ${ }^{26}$ This further alludes that the current outbreak of Covid-19 could have more to do with blood group type. More research is needed to assess the correlation between blood type and Covid-19 mortality properly.

Additionally, the South Asian demographic shows a reduced percentage of the elderly population in comparison to Europe and the Americas, possibly contributing to low mortality. South Asia has a $6 \%$ population $^{27}$ of those aged 65 and above as compared to $19.2 \%$ and $16 \%$ of Europe ${ }^{28}$ and North America ${ }^{29}$, respectively. Studies in China and the US confirm that despite Covid-19 being inclusive towards all demographics, it can be exceptionally fatal for those 65 years of age and above. ${ }^{30} 31$ This might be a reason as to why the highest number of Covid-19 casualties were 
reported in Italy $(32,610)$, UK $(36,001)$, Spain $(27,459)$, and the US $(88,523)$, since these countries have an elderly population (>65 years) of $23.1 \%,{ }^{32} 18 \%,{ }^{33} 17 \%,{ }^{34}$ and $22 \%{ }^{35}$ respectively as compared to only $6.2 \%, 4.3 \%$, and $5.2 \%$ of the most populous countries of South Asia (i.e., India, ${ }^{36}$ Pakistan, ${ }^{37}$ and Bangladesh) $)^{38}$.

Furthermore, international inbound and outbound movement also impacted Covid-19's transmission, as per studies documented in China. ${ }^{39}$ Limited movements across borders in South Asia could lead to a slower spread of the disease. On average, the total annual inbound and outbound flights in South Asian countries is significantly lower than the number of annual flights observed in Europe and North America. According to the World Bank data, South Asia, excluding Afghanistan, had a total of 24,680 incoming flights in 2018, whereas the North American region of Canada and the US had 100,879 while the UK, alone, reported 36,316 incoming flights during the same year. ${ }^{40}$ Fewer incoming flights to South Asian countries could have limited the exposure to foreigners carrying the illness, thereby reducing the spread of the virus. Thus, the possibility of transmission of the virus from foreign countries is significantly reduced, lowering the rate of transmission in South Asia as compared to the transmission rate in Europe and North America.

An earlier imposition of strict lockdown in South Asia might also have played a role in keeping the caseload of Covid-19 in check. According to the Covid-19 Government Response Stringency Index, at a scale of 0-100 (with 100 as the strictest lockdown stringency score), South Asian countries have the lockdown stringency scores in the 80s except for Afghanistan which has a score of 78.7. ${ }^{41}$ In comparison, the majority of the European countries, including Italy, have lockdown stringency scores in the 60s ${ }^{42}$ Moreover, the South Asian countries imposed countrywide lockdowns soon after the reporting of the earliest cases of Coronavirus. For instance, Pakistan imposed a strict lockdown on March 23 with the assistance of army ${ }^{43}$ when the total number of Coronavirus patients in the country was only $875 .{ }^{44}$ Meanwhile, Western European countries such as Italy and the UK delayed the imposition of strict lockdown despite the Covid-19 cases were significantly surpassing daily. ${ }^{45}$ That is, Italy imposed a lockdown ${ }^{46}$ on March 8 when the nationwide Covid-19 cases had surpassed 7,375, ${ }^{47}$ while the UK imposed a full lockdown ${ }^{48}$ on March 24 at the time when the cases had crossed 8,000. ${ }^{49}$ Moreover, in the initial phases of lockdown there, the locals did not follow the government's instructions. ${ }^{50}$ They continued to come out of their houses, defying lockdown in the spirit of upholding their freedom. ${ }^{51}$ Unlike South 
Asian countries, the European countries' local governments did not use force to restrict people to their homes. Subsequently, the Covid-19 cases spiked there, eventually becoming out of control, causing thousands of deaths within a few weeks.

Lastly, the prevalence of existing disease trends in South Asia can be a factor for better immunity. Preliminary research suggests a negative association ${ }^{52}$ between the incidence of malaria and Covid-19. Countries affected with malaria appear to be relatively safer from Covid-19 (the figure below shows this association).

\section{Figure 1: Incidence of Malaria and Covid-19}

\section{Malaria}

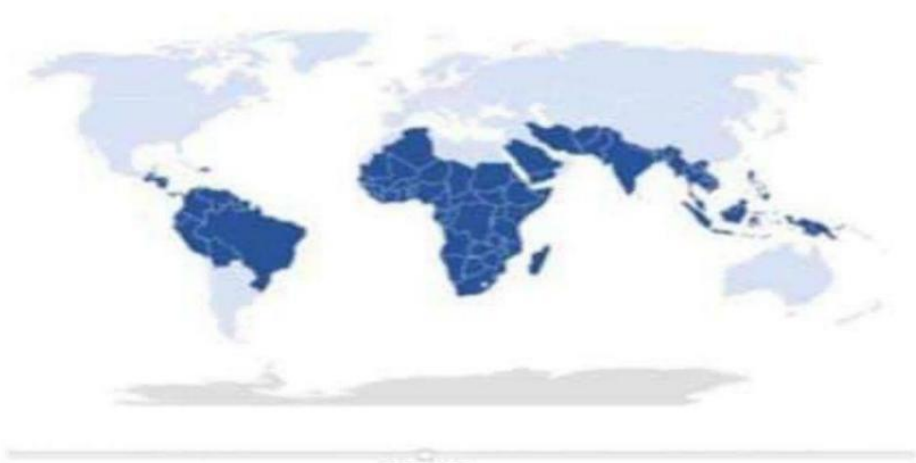

COVID-19

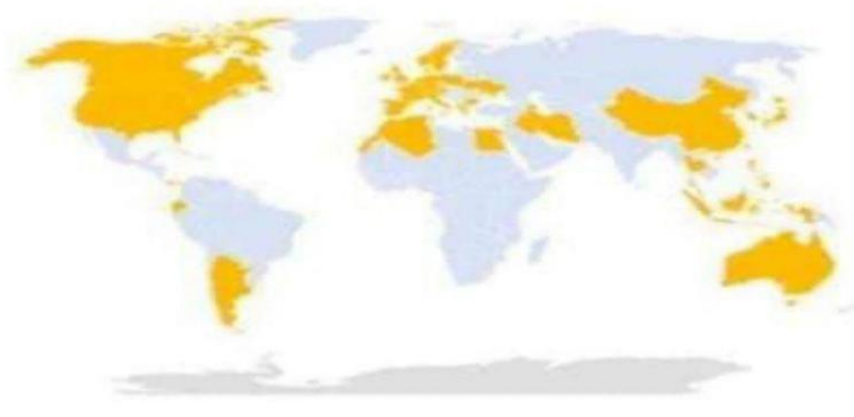

[In the figure above, the Blue region represents countries where malaria has caused more than 0.1 deaths per million inhabitants. Yellow region shows countries where Covid-19 has caused a similar level of fatalities. (Source: Guerrini et al., 2020; Nasir et al., 2020) ${ }^{53}$ ] 
A possible explanation for such a correlation could be from the prolific use of antimalarial drugs within these regions. Although, there is a lack of consensus among researchers for the overall beneficial use of antimalarial treatment for Covid-19, certain antiviral drugs, such as remdesivir and chloroquine, were effective in controlling the infection in vitro. ${ }^{54}$ Similarly, a study done in France with a limited sample size (36 patients were used, with 20 receiving the treatment and 16 serving as the control group) suggested that the use of hydroxychloroquine along with azithromycin was effective in reducing the viral load. ${ }^{55}$

The use of these drugs as a part of a potential treatment plan for Covid-19 is controversial as some research highlights that not only does hydroxychloroquine (given with or without a macrolide, such as azithromycin) have no confirmed benefit but further increases the frequency of ventricular arrhythmias, possibly contributing to more in-hospital death. ${ }^{56}$

The largest country in South Asia, India, is severely afflicted by malaria. According to the World Health Organization (WHO), in 2018, nineteen countries in Sub-Saharan Africa and India carried almost $85 \%$ of the global malaria burden. ${ }^{57}$ As a result, South Asian (and African), as compared to the people in other regions, have consumed more antimalarial drugs. While anecdotal evidence in South Asia imply that antimalarial drugs contribute to Covid-19 recovery, greater research with far better randomized control trials is necessary before any treatments are established.

Likewise, research has confirmed a negative correlation ${ }^{58}$ between the occurrence of tuberculosis (TB) and Covid-19. ${ }^{59}$ Contrary to low-burden TB countries, high-burden TB South Asian countries have long had a national Bacillus Calmette-Guerin (BCG) childhood vaccination policy for everyone ${ }^{60}$ Countries without universal policies of BCG vaccination (i.e., Italy, Spain, and the US) have been hit hard by Covid-19 relative to countries with universal BCG policies. ${ }^{61}$

BCG vaccinations have previously shown to decrease respiratory tract infections in non-Covid-19 patients as well. In 2005, Ohrui and colleagues conducted a prospective cohort study that points out that administering the BCG vaccine to the elderly (age > 65 years) decreases their risk of pneumonia regardless of their comorbidities. ${ }^{62}$ An additional case-control study by researchers in Bangladesh suggests that severely malnourished children with pneumonia and bacteremia had no prior vaccination to $\mathrm{BCG}$, implying that the benefits of the vaccination might be far greater than its initial point of use. ${ }^{63}$ Although these various studies show the benefit of BCG administration to 
non-Covid-19 patients facing respiratory illnesses, alternative studies show patients with Covid19 who were vaccinated with BCG had non-specific effects. These non-specific beneficial effects were the reduction of respiratory tract infections, antiviral effects along with reduced viremia which were tested previously in animal samples. ${ }^{64} \mathrm{~A}$ further clinical investigation should focus on the impact of BCG and Covid-19 morbidity to assess why some countries who have a vaccination trend are doing better than those without such vaccination policies. A research article published by Nature magazine suggests that the extent of possible genetic mutation of Covid-19 in different geographic populations can also be the reason for different transmission rates. ${ }^{65}$ Countries like Iran might have a mutated version of Covid-19, implying the death of many, but research also shows that Iran had a late policy of BCG vaccination, which began in 1984, thereby putting a lot of their senior population at risk and possible death. ${ }^{66}$

\section{The other side of the story:}

Since the research behind the observations illustrated in this article is preliminary, the observations remain subjects for discussion. There can be other reasons, such as lack of Covid-19 testing facilities or low reporting protocols, which may be masking the actual Covid-19 patients in South Asia. In general, the South Asian countries have weaker healthcare systems and fewer healthcare budgets than those of Europe and North America (US and Canada). Prominent South Asian countries such as India, Pakistan, and Bangladesh have asked for testing kits from China and other countries as donations because they significantly lack those kits for testing their millions of people.

The weak healthcare systems of South Asia, coupled with other factors such as poverty, high population density, and lack of healthcare policy implementation, pose stringent risks of massive Covid-19 spread in South Asia. South Asia is home to millions of daily wagers working in an informal economy. Poverty can force daily wagers to come out of the lockdown sooner or later, which can spread the virus. This happened during the Spanish pandemic flu back in 1918, when the locals disregarded lockdown as they became tired of staying at their homes during the first wave of the pandemic. Consequently, the second wave of the Spanish flu emerged, causing the number of casualties to rise to 20 to 50 million from the first wave's casualties of 3 to 5 million. ${ }^{67}$

In a recent episode of defiance of lockdown, already, thousands of migrant workers have made protests on the roads in Mumbai in India, maintaining that they are on the verge of dying from 
hunger due to the lockdown. ${ }^{68}$ Similarly, people are not following precautionary measures in Pakistan as they have started flocking into the markets, particularly in the major cities due to the recent softening of the lockdown by the local government. Many are not even wearing masks as they are now considering the threat of Covid-19 less stringent, primarily because the Covid-19 has not done as much damage in the region as it has caused in Europe and North America.

With the ease in lockdown, if people continue to come out of their homes without following the precautionary measures, then the crowding can result in spreading the Covid-19 vociferously. In particular, the existing high population density of South Asia can also increase the gravity of the risk of quicker and momentous spread of the pandemic in the region. Unfortunately, the existing healthcare systems of South Asian countries, particularly Pakistan, Afghanistan, Bangladesh, and Sri Lanka, have limited capacities to cater healthcare to the general population. They have a limited number of ventilators and healthcare equipment. ${ }^{69}$ Thus, in such a scenario, the local healthcare systems will not be able to control the spread of the disease if the existing number of Covid-19 cases gets multiplied and crosses beyond the range which the local healthcare systems can manage.

We suggest that the local governments should sit together and decide on implementing immediate and effective measures to stop the further spread of the pandemic. They should collaborate and share technical and healthcare expertise to devise and implement comprehensive strategies to stabilize not only their existing healthcare systems but also stop the spread of disease. In this regard, the recent hosting of the joint virtual SAARC conference of South Asian countries by Pakistan, is a commendable step. ${ }^{70}$ In the conference, the representatives of SAARC discussed strategies for preventing the spread of Coronavirus in the region. ${ }^{71}$ This conference is a fine example of regional cooperation in the times of the spread of the ongoing pandemic Covid-19.

Similarly, countries should help the poverty-stricken, especially daily wagers, through their emergency welfare governance assistance programs. Programs such as the 'Ehsas Emergency Cash Program, ${ }^{72}$ launched by the government of Pakistan aimed at providing a direct cash transfer to the daily wagers and those who have become unemployed due to the lockdown, can also prove to be beneficial for curbing the harmful impacts of the Covid-19. 
In a nutshell, on the one hand, South Asia seems to be a region less affected by the Covid-19 due to several factors such as the warmer and sunnier climate, smaller percentage of the population of old age people, existing disease' trends, and lesser inbound and outbound movements as compared to Europe and North America. On the other hand, the South Asian countries have weaker healthcare infrastructure to control the pandemic. Moreover, poverty, high population density, and poor sanitation pose the threat of the spread of disease. All these factors, combined with the recent easing of lockdown restrictions in the region, could lead to spikes in rates of Covid-19 infections.

As long as there is no vaccine, there is no place for complacency in the fight against Covid-19. South Asia should prepare for the worst by swiftly mobilizing local resources, quickly ramping up capabilities, and thoroughly implementing the proposed guidelines. The public should practice prevention and precaution. The national governments should address stigma related to Covid-19. Finally, the international community must increase its technical assistance to mitigate the threats of the pandemic in populous South Asia.

\section{Notes and References:}

${ }^{1}$ For details, see total number of cases as of $31^{\text {st }}$ May 2020: COVID-19 Coronavirus Pandemic. Coronavirus Cases. Worldometer. https://www.worldometers.info/coronavirus/ . Updated 31 May 2020. Accessed 31 May 2020. [Hereinafter: Coronavirus Cases].

${ }^{2}$ For details, see: Davis K, Stremikis K, Squires D, Schoen C. Mirror, Mirror on the Wall, 2014 Update: How the U.S. Health Care System Compares Internationally. The Commonwealth Fund. https://www.commonwealthfund.org/publications/fund-reports/2014/jun/mirror-mirror-wall2014-update-how-us-health-care-system, Updated 16 June 2014. Accessed 20 May 2020.

${ }^{3}$ Ibid. See also: Cash R, and Patel V. Has COVID-19 subverted global health? The Lancet: Perspectives. 05 Mat 2020: 395: 1687-1688. doi: https://doi.org/10.1016/S0140-6736(20)310898 .

${ }^{\frac{8}{4}}$ For details, see: Coronavirus Cases, supra note 1.

${ }^{5}$ The total number of Covid-19 cases in South Asia, as of 29 May 2020 are 298336; whereas, the total population of South Asia is 1.9 billion or 1937 million. Calculation gives 154 cases per million population in South Asia. For details about Coronavirus Cases in South Asian countries, see: Coronavirus Cases, supra note 1. For details about South Asian population, see: Southern Asian Population (LIVE). Worldometer. https://www.worldometers.info/worldpopulation/southern-asia-population/ Updated 22 May 2020. Accessed 22 May 2020.

${ }^{6}$ Considering US and Canada, only 
${ }^{7}$ For details, see: Coronavirus Cases, supra note 1.

${ }^{8}$ Ibid.

9 For instance, see: India's poor testing rate may have masked coronavirus cases. Aljazeera. https://www.aljazeera.com/news/2020/03/india-poor-testing-rate-masked-coronavirus-cases200318040314568.html Updated 18 May 2020. Accessed 23 May 2020.

${ }^{10}$ See: Fliegauf E, Ayres A. Coronavirus in South Asia, April 2, 2020: Crowds in India and Pakistan Thwart Social Distancing. Council on Foreign Relations. https://www.cfr.org/blog/coronavirus-south-asia-april-2-2020-crowds-india-and-pakistan-thwartsocial-distancing. Updated 02 April 2020. Accessed 20 May 2020.

${ }^{11}$ See the details of total number of tests conducted by the 8 South Asian countries as given the number in the tab/section of Asia: Coronavirus Cases, supra note 1.

${ }^{12}$ For details, see the data in: Cases as of 31 May.xlsx

${ }^{13}$ See:Coronavirus, Cases. Worldometers. https://www.worldometers.info/coronavirus/\#countries Updated 31 May 2020. Accessed 31 May 2020.

${ }^{14}$ Ibid.

15 Hashim A. The curious case of South Asia's 'low' coronavirus deaths. Aljazeera. https://www.aljazeera.com/news/2020/05/curious-case-south-asia-coronavirus-deaths-

200518090320358.html Updated 18 May 2020. Accessed 23 May 2020.

${ }^{16}$ Hao, K. Warmer weather could slow the spread of coronavirus-but not by much. MIT Technology Review. https://www.technologyreview.com/2020/03/19/905217/coronavirus-spreadcould-slow-with-warmer-weather/ . Updated 19 March 2020. Accessed 22 May 2020.

17 Martineau AR, JollifFe D, Hooper R, et. al. Vitamin D supplementation to prevent acute respiratory tract infections: systematic review and meta-analysis of individual participant data. BMJ. 2017: 356:i6583: 1-3. doi: 10.1136/bmj.i6583

${ }^{18}$ For example, see: Illie PC, Stefanescu S, Smith L. The role of vitamin D in the prevention of coronavirus disease 2019 infection and mortality. The role of vitamin D in the prevention of coronavirus disease 2019 infection and mortality. Aging Clin Exp Res - Springer. 2020. https://doi.org/10.1007/s40520-020-01570-8 . See also: Daneshkhah A, Agrawal V, Eshein A, Subramanian H, Roy HK, Backman V. The Possible Role of Vitamin D in Suppressing Cytokine Storm and Associated Mortality in COVID-19 Patients. medRxiv. 2020. doi: https://doi.org/10.1101/2020.04.08.20058578 . See also another study: Grant WB, Lahore H, McDonnell SL, et al. Evidence that Vitamin D Supplementation Could Reduce Risk of Influenza and COVID-19 Infections and Deaths. Nutrients. 2020:12(4):988. doi:10.3390/nu12040988 . For more details, see another study: Lau FH, Majumdar R, Torabi R, Saeed F, Hoffman R, Cirillo JD, et. al. Vitamin D Insufficiency is Prevalent in Severe COVID-19. medRxiv. 28 April 2020. doi: https://doi.org/10.1101/2020.04.24.20075838.

${ }^{19}$ Reinberg S. Healthy Vitamin D Levels Could Be Linked to COVID-19 Survival. U.S.News. https://www.usnews.com/news/health-news/articles/2020-05-08/healthy-vitamin-d-levels-couldbe-linked-to-covid-19-survival Updated 08 May 2020. Accessed 22 May 2020.

${ }^{20}$ Zaman R, Pervez M, Jakaria M, Sayeed MA. Study of ABO and Rh-D blood group among the common people of Chittagong city corporation area of Bangladesh. J. Pub. Health \& Epidemiology. September 2020: 7(9): 305-310: doi: 10.5897/JPHE2015.0727

${ }^{21}$ For details, see: Zhao J, Yang Y, Huang H, et. al. Relationship between the ABO Blood Group and the COVID-19 Susceptibility. medRxiv. 2020: 1-18.doi: https://doi.org/10.1101/2020.03.11.20031096 . [Hereinafter: Zhao et. al.].

${ }^{22}$ See: Zhao et. al., supra note 20, at 3. 
${ }^{23}$ See: Zhao et. al., supra note 20 , at 6. .

${ }^{24}$ Zietz M, and Tatonetti NP. "Testing the Association between Blood Type and COVID-19 Infection, Intubation, and Death." Preprint. Infectious Diseases (except HIV/AIDS), April 11, 2020. https://doi.org/10.1101/2020.04.08.20058073.

${ }^{25} \mathrm{Id}$, at 9.

${ }^{26}$ Batool Z, Durrani SH, \& Tariq S., Association of Abo and Rh Blood Group Types to Hepatitis B, Hepatitis C, Hiv And Syphillis Infection, A Five Year' Experience in Healthy Blood Donors in a Tertiary Care Hospital. 92. J. Ayub Med. Coll Abbottabad. 2017: 29(1): 90-92. https://jamc.ayubmed.edu.pk/index.php/jamc/article/view/1729. Updated n.d. 2017. Accessed 23 May 2020.

${ }^{27}$ For details, see; Population ages 65 and above (\% of total population). The World Bank. 2019. https://data.worldbank.org/indicator/SP.POP.65UP.TO.ZS?contextual=population-by-

age\&view=map Updated n.d. 2019. Accessed 20 May 2020. [Hereinafter: The World Bank].

${ }^{28}$ For details, see: A look at the lives of the elderly in the EU today: What is the share of the elderly (65 or over) among the total population? Eurostat. https://ec.europa.eu/eurostat/cache/infographs/elderly/index.html Updated n.d. 2017. Accessed 22 May 2020.

${ }^{29}$ See: The World Bank, supra note 25.

${ }^{30}$ For example, see: Verity R, Okell L, Dorigatti I, Winskill P, Whittaker C, Imai N, et. al. Estimates of the severity of coronavirus disease 2019: a model-based analysis. Lancet Infect Dis. 2020: 20: 669-677. doi: :https://doi.org/10.1016/S1473-3099(20)30243-7. See also: Severe Outcomes Among Patients with Coronavirus Disease 2019 (COVID-19) — United States, February 12-March 16, 2020. Morbidity and Mortality Weekly Report (MMWR). Centers for Disease Control and Prevention. https://www.cdc.gov/mmwr/volumes/69/wr/mm6912e2.htm?s_cid=mm6912e2_w . Published 18 March 2018. Updated 27 March 2020. Accessed 20 May 2020.

${ }^{31}$ Liu K, Chen Y, Lin R, Han K. Clinical features of COVID-19 in elderly patients: A comparison with young and middle-aged patients. $J$ Infect. 2020: doi: 10.1016/j.jinf.2020.03.005

32 See: Percentage of elderly population in Italy from 2009 to 2020. Statista.Com. https://www.statista.com/statistics/785104/elderly-population-in-italy/ Updated 2020. Accessed 15 May 2020.

${ }^{33}$ Hill A, Fears of demographic time bomb in UK are unfounded, says study. The Guardian. https://www.theguardian.com/science/2019/nov/19/fears-of-demographic-timebomb-in-uk-areunfounded-says-study Updated 19 Nov 2019. Accessed 15 May 2020.

${ }^{34}$ Fernandez JL, Parapar C, Ruiz M. Population Ageing. Lychnos - Notebooks of the Foundation General CSIC, http://www.fgcsic.es/lychnos/en_EN/articles/population_ageing Updated n.d. Accessed 19 May 2020.

${ }^{35}$ For details, see: Share of old age population (65 years and older) in the total U.S. population from 1950 to 2050. Statista.Com. https://www.statista.com/statistics/457822/share-of-old-agepopulation-in-the-total-us-population/ Updated 2020. Accessed 17 May 2020.

36 See: India - Population Ages 65 And Above (\% Of Total). Trading Economics. https://tradingeconomics.com/india/population-ages-65-and-above-percent-of-total-wb-data.html Updated May 2020. Accessed 19 May 2020.

37 See the actual data at: Pakistan - Population Ages 65 And Above (\% Of Total). Trading Economics. https://tradingeconomics.com/pakistan/population-ages-65-and-above-percent-oftotal-wb-data.html Updated May 2020. Accessed 19 May 2020. 
38 See: Bangladesh - Population Ages 65 And Above (\% Of Total). Trading Economics. https://tradingeconomics.com/bangladesh/population-ages-65-and-above-percent-of-total-wbdata.html Updated May 2020. Accessed 19 May 2020.

${ }^{39}$ Chinazzi M, Davis JT, Ajelli M, Gioannini C, Litvinova M, Merler S. et. al. The effect of travel restrictions on the spread of the 2019 novel coronavirus (COVID-19) outbreak. Science. 24 Apr 2020: 368(6489): 395-400. doi: 10.1126/science.aba9757 . See also: Du Z, Wang L, Cauchemez S, Xu X, Wang X, Cowling B, Meyers L. Risk for Transportation of Coronavirus Disease from Wuhan to Other Cities in China. Emerg Infect Dis. 2020: 26(5): 1049-1052. doi:10.3201/eid2605.200146 .

40 For details, see: International tourism, number of arrivals. The World Bank Data. https://data.worldbank.org/indicator/ST.INT.ARVL?end=2018\&start=1995\&view=map Updated 2018. Accessed 21 May 2020.

${ }^{41}$ For details, see the COVID-19 Government Response Stringency Index as given in: Coronavirus Government Response Tracker. Blavatnik School of Government - University of Oxford. https://www.bsg.ox.ac.uk/research/research-projects/coronavirus-government-response-tracker Updated 07 May 2020. Accessed 27 May 2020.

${ }^{42}$ Ibid.

${ }^{43}$ See: Pakistan: Army deploys to enforce countrywide lockdown measures over COVID-19 as of March 23 /update 9. Garda World - News Alert. https://www.garda.com/crisis24/newsalerts/325761/pakistan-army-deploys-to-enforce-countrywide-lockdown-measures-over-covid19-as-of-march-23-update-9 Updated 23 March 2020. Accessed 21 May 2020.

${ }^{44}$ For more details, see the chart of Coronavirus cases in Pakistan as given in: Pakistan: Coronavirus Cases. Worldometer. https://www.worldometers.info/coronavirus/country/pakistan/ Updated 22 May 2020. Accessed 23 May 2020.

45 See: McCann A, Popovich N, Wu J. Italy's Virus Shutdown Came Too Late. What Happens Now? The New $\quad$ York https://www.nytimes.com/interactive/2020/04/05/world/europe/italy-coronavirus-lockdownreopen.html. Updated 05 April 2020. Accessed 13 May 2020.

${ }^{46}$ Horowitz J, Bubola E. On Day 1 of Lockdown, Italian Officials Urge Citizens to Abide by Rules. The New York Times. https://www.nytimes.com/2020/03/08/world/europe/italy-coronavirusquarantine.html Published 08 March 2020. Updated 19 March 2020. Accessed 13 May 2020.

47 See: Italy: Coronavirus Cases, WorldoMeters, 2020, https://www.worldometers.info/coronavirus/country/italy/

${ }^{48}$ See: Bruton FB. U.K. government imposes 3-week national lockdown, enforced by police, to contain coronavirus. NBC News. https://www.nbcnews.com/news/world/uk-governmentimposes-3-week-national-lockdown-enforced-police-contain-n1167141 Updated 24 March 2020. Accessed 21 May 2020.

49 See: United Kingdom: Coronavirus Cases. WorldoMeter. https://www.worldometers.info/coronavirus/country/uk/ Updated 29 May 2020. Accessed 29 May 2020.

${ }^{50}$ See: Horowitz \& Bubola, supra note 45.

${ }^{51}$ For instance, see: House party revellers sent packing by police after ignoring lockdown. Express \& Star. https://www.expressandstar.com/news/uk-news/2020/03/26/house-party-revellers-sentpacking-by-police-after-ignoring-lockdown/ Updated 26 March 2020. Accessed 20 May 2020. 
${ }^{52}$ Goswami RP, Mittal D, Goswami RP. Interaction between malarial transmission and BCG vaccination with COVID-19 incidence in the world map: A cross-sectional study. medRxiv. 08 April 2020: doi: https://doi.org/10.1101/2020.04.03.20052563.

Also, see: Guerrini I, Oshadiya M, Potential Link between Anti Malaria Prophylaxis and the Prevention of COVID-19 Infection. https://docs.google.com/document/d/12YDytbAsZaruGlhFO7eTTgxSH_BuxJtwFmbhqpkPPSk/ mobilebasic?fbclid=IwAR2 wXhG5woobpV5DAuHxnf7YOxalQiCkPMXrUL2z6SIa0AJGovbJ9ATq7A

${ }^{53}$ Javed N, Jamil F, Khan MS. "How Do We Explain the Low Covid-19 Caseload in Africa (so Far)?” Daily Maverick. Accessed June 1, 2020.

https://www.researchgate.net/publication/341464136_How_do_we explain the low_Covid19 caseload_in_Africa_so_far.

${ }^{54}$ Wang M, Cao M, Zhang L, Yang X, Liu J, Xu M, Shi Z, Hu Z, Zhong W, and Xiao G. "Remdesivir and Chloroquine Effectively Inhibit the Recently Emerged Novel Coronavirus (2019NCoV) in Vitro." Cell Research 30, no. 3 (March 2020): 269-71. https://doi.org/10.1038/s41422020-0282-0.

${ }^{55}$ Gautret P, Lagier JC, Parola P, Hoang VT, et al. "Hydroxychloroquine and Azithromycin as a Treatment of COVID-19: Results of an Open-Label Non-Randomized Clinical Trial." International Journal of Antimicrobial Agents, March 20, 2020, 105949. https://doi.org/10.1016/j.ijantimicag.2020.105949.

${ }^{56}$ Mehra MR, Desai SS, Ruschitzka F, and Patel AN. "Hydroxychloroquine or Chloroquine with or without a Macrolide for Treatment of COVID-19: A Multinational Registry Analysis." The Lancet, May 22, 2020. https://doi.org/10.1016/S0140-6736(20)31180-6.

${ }^{57}$ WHO. World malaria report 2019. World Health Organization. 04 December 2019.

${ }^{58}$ Rajasingham-Senanayke D. BCG Vaccine Fighting Coronavirus in South Asia. Inter Press Service (IPS). http://www.ipsnews.net/2020/04/bcg-vaccine-fighting-coronavirus-south-asia/ Published 20 April 2020. Updated 29 May 2020. Accessed 30 May 2020. See also: Martin BK. Map suggests TB vaccine may help prevent Covid-19. Asia Times. https://asiatimes.com/2020/04/map-suggests-tb-vaccine-may-help-prevent-covid-19/ Updated 01 April 2020. Accessed 28 May 2020.

${ }^{59}$ Miller A, Reandelar MJ, Fasciglione K, Roumenova V, Li Y, Otazu G. Correlation between universal BCG vaccination policy and reduced morbidity and mortality for COVID-19: an $\begin{array}{llllll}\text { epidemiological } & \text { study. } & \text { MedRXiV. } & 28 & \text { March } & \text { 2020: doi: }\end{array}$ https://doi.org/10.1101/2020.03.24.20042937.

${ }^{60}$ See: A Database Of Global BCG Vaccination Policies And Practices, in, The BCG World Atlas, $2^{\text {nd }}$ Edition, Available at: http://bcgatlas.org/index.php

${ }^{61}$ This is evident from the coronavirus cases in these countries. For details, see: COVID-19 Coronavirus Pandemic: Coronavirus Cases. WorldoMeters. Last updated 29 May 2020, https://www.worldometers.info/coronavirus/\#countries

${ }^{62}$ Ohrui T, Nakayama K, Fukushima T, Chiba H, Sasaki H. Prevention of elderly pneumonia by pneumococcal, influenza and BCG vaccinations. Japanese J. Geriatrics. 2005: 42(1):34-36. doi: 10.3143/geriatrics.42.34 .

${ }^{63}$ Chisti MJ, Salam MA, Ahmed T, et al. Lack of BCG vaccination and other risk factors for bacteraemia in severely malnourished children with pneumonia. Epidemiol Infect. 2015:143(4):799-803. doi:10.1017/S0950268814001368 . 
${ }^{64}$ Rajarshi K, Chatterjee A, Ray S. BCG vaccination strategy implemented to reduce the impact of COVID-19: Hype or Hope? Medicine in Drug Discovery. 2020: doi: https://doi.org/10.1016/j.medidd.2020.100049.

${ }^{65}$ Cao Y, Li L, Feng Z, et. al. Comparative genetic analysis of the novel coronavirus (2019nCoV/SARS-CoV-2) receptor ACE2 in different populations. Cell Discovery. 2020: 6 (11). https://www.nature.com/articles/s41421-020-0147-1 Updated 24 February 2020. Accessed 22 May 2020.

${ }^{66}$ Miller A, Reandelar MJ, Fasciglione K, Roumenova V, Li Y, Otazu G. Correlation between universal BCG vaccination policy and reduced morbidity and mortality for COVID-19: an

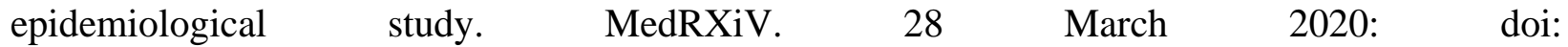
https://doi.org/10.1101/2020.03.24.20042937.

${ }^{67}$ Stellino M. Fact check: Was second wave of Spanish flu worse? Did it kill at least 20 million people? USA Today. https://www.usatoday.com/story/news/factcheck/2020/04/25/fact-checktotal-deaths-each-spanish-flu-wave-unknown/3024648001/ Updated 25 April 2020. Accessed 22 May 2020.

68 India ignites protest by migrant workers over lockdown extension. TRT World. https://www.trtworld.com/asia/india-ignites-protest-by-migrant-workers-over-lockdownextension-35407 Updated 14 April 2020. Accessed 23 May 2020.

${ }^{69}$ For instance, as discussed in: Ibrahimi SS, and Kamal SM. The Battles That Can Cost South Asia the War Against COVID-19. The Diplomat. https://thediplomat.com/2020/04/the-battlesthat-can-cost-south-asia-the-war-against-covid-19/ . Updated 30 April 2020. Accessed 30 May 2020.

Also see: Khan MS, Latif F. "The Coronavirus and Pakistan: Why People Must Immediately Begin Social Distancing?" The National Interest. Accessed May 31, 2020. https://www.researchgate.net/publication/341464110 5182020_The_Coronavirus_and_Pakistan Why_People_Must_Immediately_Begin_Social_Distancing.

70 Pakistan hosts SAARC video conference on COVID-19. Arab News. https://www.arabnews.pk/node/1663711/pakistan Updated 24 April 2020. Accessed 21 May 2020.

${ }^{71}$ For details, see: Pakistan to host SAARC video conference on coronavirus on 24 April. The Print. https://theprint.in/world/pakistan-to-host-saarc-video-conference-on-coronavirus-on-24april/407848/ Updated 23 April 2020. Accessed 21 May 2020.

72 For details about the Ehsas Emergency Cash Program, see: https://www.pass.gov.pk/Detailf90ce1f7-083a-4d85-b3e8-60f75ba0d788 